\title{
Aktivitas Pemasaran Produk Asuransi pada PT. Asuransi ASEI Cabang Padang
}

\author{
Mawar Siritoitet, Muhammad Hendra, Nazaruddin Aziz \\ Akademi Keungan Dan Perbankan "Pembangunan"AKBP Padang \\ Sekolah Tinggi Ilmu Ekonomi KBP \\ mawarsiritoitet@gmail.com
}

\begin{abstract}
This study aims to determine how product maketing at PT. Asuransi ASEI branch in increasing the sale of its products. The medhot used in this study uses qualitative data analysis as a research method that explains descriptively about product marketing activities at PT. Insurance ASEI branch Padang.Based on the results of research that has been made at PT. Insurance ASEI branch Padang By Promotion, Place, Evens, and Information about the products contained in the Insurance the Padang branch of ASEI.
\end{abstract}

Keywords : Promotion, Place, Evens And Informatoin

\section{PENDAHULUAN}

Pengetahuan ilmu teknologi saat ini membuat secara sepintas manusia mengalami kemajuan ekonomi yang modern di dunia. Pandangan masyarakat mengenai asuransi sedikit banyak mengalami peningkatan. Dilihat dari perkembangan sosialisasi yang telah dilakukan oleh perusahaan Asuransi di Indonesia, mengenai betapa pentingnya peran asuransi bagi masyarakat. Asuransi merupakan perjanjian antara dua pihak atau lebih, yang mana pihak penanggung mengikatkan diri kepada tertanggung, dan menerima premi asuransi, untuk memberikan penggantian kepada tertanggung akibat kerugian/kerusakan kehilangan keuntungan yang diharapakan atau tanggungjawab hukum pihak ketiga yang mungkin akan diderita tertanggung, yang timbul dari suatu peristiwa yang tidak pasti. Asuransi merupakan lembaga keuangan non Bank yang membantu masyarakat untuk menghadapi berbagai risiko, kematian, bencana, kebakaran kerugian dan kecelakaan.

Bangunan merupakan salah satu asset yang memiliki banyak risiko. Seperti diketahui, harga rumah dijaman sekarang tidak bisa dikatakan murah. Maka dari itu, untuk memberikan kenyamanan terhadap asset berupa tempat tinggal seperti rumah, dan untuk meminalisir risiko dan kerugian tersebut, maka asuransi kebakaran merupakan cara yang baik untuk pencegahan. Bila risiko ditanggung melalui tabungan sendiri, maka dapat mengurangi tabungan yang dimiliki, atau musibah tersebut jauh lebih besar nilainya dari tabungan yang dimiliki. Peristiwa kebakaran ini merupakan musibah yang menimpah lingkungan kehidupan manusia seperti rumah-rumah, gedung bertingkat, pusat perkantoran, bangunan pemerintah dan lain sebagainya. Perusahaan asuransi sebagai penanggung berkewajiban mengganti kerugian apabila terjadi evenemen kebakaran. Sedangkan kewajiban pihak tergantung adalah 
membayar premi kepada pihak penangung premi merupakan dalam suatu perjanjian asuransi. Melihat peristiwa-peristiwa di atas sangat jelas bawah asuransi kebakaran sangat diperlukan, dan mempunyai peluang yang sangat besar untuk dipasarkan.

Persaingan bisnis terus meningkat berkat bertambanya pengetahuan masyarakat mengenai asuransi. Masing-masing perusahaan berusaha untuk meningkatkan strategi-strategi dalam memasarkan produk yang dimiliki dengan menguasai pasar lebih luas. Hal itu berguna untuk kesejaterahaan perusahaan dan dapat mengembangkan usahanya menjadi semakin baik dan inovatif. Maka hal tersebut dapat diharapkan dan menjadikan perusahaan tersebut semakin dipercaya oleh konsumen.

Di dalam perasuransian, persaingan merupakan hal yang diperhatikan terutama dalam bidang pemasarannya. Dapat dilihat dimana perusahaanperusahaan berupaya untuk meningkatkan reputasi perusahaan agar tetap dipercaya oleh peserta asuransi yang menjalin hubungan kerjasama dan para calon peserta asuransi baru. Perusahaan dapat terjaga eksistensinya tergantung dari bagaimana perusahaan melihat peluang pasar yang ada, terutama dalam bidang pemasaran.

Salah satu perusahaan yang memiliki produk asuransi kebakaran yaitu PT Asuransi Ekspor Indonesia (Persero) dengan nama Produk Polis Standar Asuransi Kebakaran Indonesia (PSAKI) yang memiliki pengalaman dan kemampuan di bidang asuransi umum dan jaminan. Asuransi Asei memiliki produk asuransi kebakaran yang dikeluarkan oleh asuransi umum Indonesia (AUI) yang memberikan perlindungan pada harta yang dipertanggungkan akibat dari kebakaran, (fire), petir (lighting), ledakan (explosion), kejatuhan pesawat terbang (Aircraft), asap (smoke). Oleh karena itu untuk mengetahui sampai mana sudah perkembangan produk tersebut maka diperlukan suatu analis yang dapat menilai kinerja pemasaran produk tersebut. Strategi pemasaran merupakan hal penting bagi perusahaan. Dimana dengan strategi pemasaran yang baik dapat meningkatkan penjualan produk yang dihasilkan. Hal ini dapat dilihat dari tabel dibawah ini.

\section{Tabel 1}

Jumlah Penjualan Produk Pada PT. Asuransi ASEI Cabang Padang

\begin{tabular}{ccc}
\hline Nama produk & Tahun & Jumlah \\
\hline Asuransi kebakaran & 2019 & $5.767 .016 .957,84$ \\
Asuransi Kebakaran & 2020 & $4.420 .400 .297,74$ \\
Asuransi kebakaran & 2021 & $86.012 .789,63$ \\
\hline
\end{tabular}

Sumber : PT. Asuransi ASEI cabang Padang

Dari tabel diatas dapat dilihat bahwa jumlah penjualan produk pada PT. Asuransi Asei cabang Padang pada tahun 2019-2021 mengalami peningkatan dan penurunan. Pada tahun 2019 jumlah penjualan produk pada PT. Asuransi ASEI cabang Padang meningkat dengan jumlah Rp 5.767.016.957,84, pada tahun 2020 mengalami penurunan dengan jumlah $\mathrm{Rp}$ 4.420.400.297,74 dan pada tahun 2020-2021 jumlah penjualan produk pada 
PT. Asuransi ASEI cabang Padang mengalami penurunan dengan sejumlah Rp 86.012.789,63.

\section{METODE PENELITIAN} yakni:

Didalam penelitian ini penulis menggunakan metode dengan dua cara

\section{Metode Pengumpulan Data}

a. Studi Perpustakaan

Pengumpulan data serta yang terkait dengan masalah yang dibahas melalui literatul-literatul yang ada baik berupa buku ataupun majalah yang berkaitan dengan penelitian.

b. Studi Lapangan

Pada studi penelitian lapangan, penulis melalukan studi langsung ke PT. Asuransi Asei cabang Padang, untuk memperoleh data serta keterangan yang diperlukan dalam penelitian.

\section{Metode Analisis Deskriptif}

Untuk menganalis data penelitian, penulis menggunakan analisis deskriptif yaitu menjelaskan secara deskriptif tentang aktivitas pemasaran produk pada PT. Asuransi Asei cabang Padang.

\section{LANDASAN TEORI}

\section{Pengertian Pemasaran}

Pemasaran merupakan suatu fungsional yang penting dalam organisasi bisnis, dimana pemasaran merupakan penunjang bagi kelangsungan hidup suatu usaha. Menurut (Makdalena, 2015) pemasaran merupakan proses dimana perusahaan menciptakan nilai bagi pelanggan, dengan tujuan untuk mendapatkan nilai dari pelanggan. Sebagai imbalannya, memberikan keuanggulan dengan menjaga konsistensi kualitas produk akan lebih menjanjikan dari pada perusahaan menciptakan produk yang murah namun kualitas yang tidak maksimal.

Konsumen juga memiliki pandangan tentang kualitas produk yang akan dikonsumsi, mayarakat biasanya membandingkan produk satu dengan produk yang lain. Menurut (Ratnasari, 2016) kualitas produk merupakan, produk atau jasa yang mendasarkan pada kemampuan untuk memuaskan kebutuhan pelanggan yang dinyatakan atau yang disalurkan langsung. Keputusan dari konsumen dalam membeli sebuah produk dipengaruhi oleh kualitas dari sebuah produk serta sebuah pelayanan, sehingga banyak sekali produsen mengabaikan kualitas produk mereka. Namun, jika produsen memperhatikan kualitas produknya, maka pembeli akan setia pada produk yang akan dibeli. Konsumen biasanya membutuhkan suatu yang menarik dan khas yang berkaitan dengan merek yang mereka beli, ketidaksesuaian citra merke dengan ambisi konsumen dapat memberikan kesempatan kepada pesaiang.

Dalam buku manajemen pemasaran (Khotler Philip, 1994) menyatakan bahwa pemasaran merupakan fungsi bisnis yang mengidentifikasih keinginan serta kebutuhan yang belum terpenuhi 
sekarang dan mengukur seberapa besar target pasar yang baik untuk dilayani oleh organisasi, menentukan berbagai produk jasa serta program yang tepat untuk melayani pasar tersebut. Jadi, pemasaran merupakan penghubung antara kebutuhan masyarakat dengan pola jawaban industri yang bersangkutan.

Adapun pengertian pemasaran menurut American Marketing Association 1960 menyatakan bahwa, pemasaran merupakan prestasi kerja kegiatan usaha yang berkaitan dengan mengalirnya barang dan jasa dari produsen sampai kekonsumen. Dalam hal ini, banyak keputusan pemasaran yang harus dibuat sebelum produk itu dihasilkan seperti keputusan produk yang dibuat, pasaranya, harga dan promosinya. Sebagai contoh pemasaran dapat berupa produk apa yang diproduksikan, apakah produk itu perlu dirancang, dikemas, dan merek apa yang digunakan untuk produk tersebut. Keputusan mengenai produk harus dikaitkan dengan sasaran pasar yang dituju.

\section{Perkembangan Manajemen Pemasaran}

Perkembangan pemasaran mulai berkembang dengan banyaknya kebutuhan manusia dan usaha melalui pertukaran. Perkembangan peradaban manusia menimbulkan penggunaan alat pertukaran, dengan adanya perkembangan mulai dikenal transaksi jual beli. Dengan adanya perkembangan barulah pemasaran merupakan kegiatan transaksi jual beli, dimana seluruh barang yang dihasilkan atau diproduksikan dengan mudah dapat terjual. Orientasi pengembangan manajemen pada saat itu telah berkembang dari orientasi produksi menjadi orientasi penjualan. Dalam hal ini penekanan utamanya adalah bagaimana barang yang dihasilkan dapat dijual, sehingga target penjualan yang ditetapkan dapat dicapai dalam rangka pencapaian tujuan keuntungan perusahaan jangka pendek. Adanya peningkatan tarif hidup masyarakat yang tercermin dalam kesejahteraan menyebabkan anggota masyarakat atau konsumen ingin dilayani lebih baik lagi, sesuai keinginan bagi pemenuhan kebutuhan hidupnya. (Assauri, 2019:5-9)

\section{Strategi Pemasaran}

Strategi pemasaran adalah salah satu langkah awal perusahaan dalam mengenalkan produk pada konsumen, karena berhubungan dengan keuntungan-keuntungan yang didapatkan oleh perusahaan. Didalam ilmu pemasaran, sebelum melakukan promosi atau pendekatan yang lainnya, segmen pasar yang dituju harus jelas.

Menurut khotler Philip, 2012 dalam bauran pemasaran ada empat konsep diantaranya yaitu produk, harga, promosi dan distribusi. Produk merupakan sesuatu yang ditawarkan di pasar untuk mendapatkan perhatian agar produk tersebut dapat memenuhi kebutuhan serta keinginan konsumen. Harga merupakan keputusan yang berkenan dengan strategi dan teknis harga, struktur diskon, atu potongan harga. Promosi merupakan aktivitas penyampaian manfaat produk kepada pelanggan agar produk 
tersebut dapat terjual. Distribusi merupakan kegiatan penyaluran barang dari produsen sampai konsumen. Adapaun bagian dari strategi pemasaran yakni:

a. Strategi pemasaran dan tujuan perusahaan

Salah satu tujuan dari perusahaan adalah untuk mempertahankan dan meningkatkan keuntungan/laba perusahaan. Usaha yang dapat dilakukan yaitu dengan cara meningkatkan penjualannya melalui usaha, membina langganan serta menguasai pasar. Tujuan ini bisa dicapai apabila bagaian pemasaran perusahaan melakukan satragi yang mantap, dan mendapatkan kesempatan atau peluang yang ada dalam pasar.

Strategi pemasaran adalah rencana yang menyeluruh, terpadu, serta menyatu dibidang pemasara, dan memberikan panduan kegiatan yang dijalankan suatu perusahaan. Dengan ain, strategi pemasaran merupakan serangkayan tujuan dan sasaran, serta peraturan yang memberi arah kepada usaha perusahaan dari waktu ke waktu. Oleh karena itu, penetapan strategi pemasaran berdasarkan atas analisis lingkungan serta internal perusahaan melalui analisis keunggulan dan kelemahan perusahaan, serta analisis kesempatan dan ancaman yang dihadapi oleh perusahaan dari lingkungannya.

b. Strategi umum dan menyeluruh perusahaan

Setiap perusahaan yang memasarkan produknya dengan menggunakan strategi pemasaran, pastilah perusahaan tersebut mencapai sasaran yang diharapkannya. Srategi pemasaran dinyatakan sebagai dasar tindakan yang mengarah pada kegiatan usaha perusahaan dalam kondisi persaingan lingkungan yang selalu berubah. Jadi, penetapan strategi yang dijalankan perusahaan harus melihat situasi dan kondisi pasar dari produknya serta posisinya dipasar. Setalah mengetahui keadaan pasar dan posisinya dipasar, maka dapat ditentukan tujuan dan sasaran yang diharapkan dalam bidang pemasaran dan bagaimana kegiatan yang dilakukan untuk mencapai tujuan tersebut.

Dalam tahap ini perusahaan harus mempunyai pandangan mengenai produk (barang atau jasa) apa yang akan ditawarkan kepada sasaran pasar dengan bidang usaha perusahan yang telah ditentukan sebelumya. Jadi, perusahaan harus menentukan produk-produk apa yang termasuk dalam produk mix sesuai dengan kebutuhan sasaran pasar tersebut. (Assauri, 2019:167-172).

\section{Lingkup Bisnis Pemasaran}

Dalam upaya untuk memenuhi kebutuhan secara menguntungkan, haruslah memikirkan apa yang dipasarkan. Terdapat sepuluh jenis unit kesatuan yang dipasarkan, yaitu barang, jasa, pengalaman, events, orang atau tempat, properties, organisasi, informasi dan promosi (Assauri, 2019:6-7). 
a. Barang adalah sebagai barang fisik, yang banyak diproduksi oleh banyak Negara dan usaha-usaha pemasaran.

b. Jasa adalah hasil kemajuan ekonomi, yaitu suatu proporsi pertumbuhan dari kegiatan manusia, yang difokuskan pada upaya menghasilkan jasa. Terdapat lebih dari $50 \%$ dari jasa yang mendukung apa yang dikenal sebagi bauran produk atau product mix. Jasa meliputi pekerjaan dipenerbangan, hotel, perusahan reltal mobil dan perawatan manusia.

c. Evens, dimana pemasar mempromosikan barang atau jasa berdasarkan waktu atau time, seperti Olimpiade atau warld cup, dipromosikan secara agresif oleh perusahaaan.

d. Orang, yang dipasarkan seperti bisnis pemasaran selebriti, yaitu merupakan suatu bisnis andalan. Demikian pula sering ditemui, bahwa setiap bintang film, mempunyai suatu agensi, seorang personal manajer, yang sering dikaitkan untuk suatu public relation.

e. Place atau tempat, seperti kota, Negara dan wilayah sering ditemui berbagai ikon yang dipromosikan. Banyak negara telah ramai-ramai secara aktif mempromosikan mancanegara sebagai pilihan tujuan wisatanya. Selain itu, beberapa negara telah mempromosihkan sebagai pilihan tempat investasi pabriknya, atau pilihan tempat kantor pusat perusahaan dan daerah tempat tinggal atau resident baru.

f. Properties yang merupakan suatu hak tidak berwujud atas kepemilikan real property, seperti financial property, saham atau obligasi.

g. Organisasi, umumnya bekerja untuk membangun suatu kekuatan, kenamaan, keunikan didalam pikiran publik sasarannya.

h. Informasi, merupakan penjelasan aktivitas organisasi medasar dari suatu perusahaan kepada pihak luar perusahaan dan masyarakat.

i. Promotion (Promosi), merupakan jenis komunikasi yang memberikan penjelasan yang meyakinkan calon konsumen tentang barang dan jasa.

\section{Sasaran Pasar}

Pada mulanya pasar dikaitkan dengan tempat pembeli atau penjual bersama-sama melakukan tempat pertukaran, adapula pengertian pasar dikaitkan dengan perekonomian yang mewujudkan pertemuan antara penjual dengan pembeli. Yang perlu diperhatikan dalam pengertian pasar terkandung penekanan perhatian terhadap individu maupun kelompok orang atau organisasi yang memiliki dua sifat penting, yaitu pertama ada minat dan kedua daya tarik pembeli terhadap barang atau jasa tersebut.

Dari uraian diatas, bahwa pasar merupakan tempat pertukaran yang potensial, baik dalam bentuk fisik sebagai tempat berkumpul, atau bertemunya para penjual dan pembeli, maupun yang tidak bersifat fisik, yang mungkin terlaksananya pertukaran karena terpenuhinya persyaratan yaitu minat, citra dan daya tarik pembeli.

Bagi perusahaan pasar merupakan sasaran untuk keberhasilan dalam mencapai tujuan dibidang pemasaran. Dalam mengukur 
keberhasilan dalam bidang pemasaran, suatu perusahaan perlu mengetahui posisinya di pasar. Posisi perusahaan dipasar antara lain dapat diketahui dari shere yang dilkukan oleh perusahaan tersebut. Yang dimaksudkan dengan shere pasar adalah besarnya bagian atau luasnya total pasar yang telah dikuasai oleh suatu perusahaan dapat dihitung dari perbandingan yang biasanya dinyatakan dalam presentase.

\section{Konsep Dasar Penjualan}

Penjualan merupakan kegiatan dari pembelian untuk terjadinya transaksi barang atau jasa. Karena itu, keinginan penjual seperti halnya pembelian yang meliputi permintaan, menemukan calon pembeli, negosiasi harga, dan syarat pembayaran. Penciptaan suatu produk merupakan usaha penjualan yang harus dilakukan, pertama-tama dalam pengenalan produk baru kepada konsumen. Adapun usaha lain dalam mencari dan menemukan calon pembeli dilakukan dengan cara bertemunya penjual dan pembeli, dan terjanyalah traksaksi penjualan (Nurdin, 2016).

\section{Implementasi}

Implementasi perusahaan adalah proses mengubah stategi-strategi serta rencana-recana pemasaran menjadi tindakan-tindakan pemasaran sehingga sasaran-sasaran pemasaran yang stragenik dapat terjadi. Strategi dan implementasi sangat erat kaitannya. Pertama, trategi menentukan kegiatan-kegiatan implementasi yang dibutuhkan. Sebagai contoh, keputusan manajemen puncak untuk "memetik hasil" sebuah produk harus dijabarkan menjadi tindakan-tindakan spesifik seperti pengalokasian dana yang kecil untuk produk tersebut, pemberian bimbingan kepada wiraniaga harga, dan peninjauan kembali usaha-usaha biro iklan untuk diarakan kepada produk-produk lain. Keputusan untuk memperhatikan sebuah produk tentu akan menjadi perhatikan kegiatan-kegiatan implementasi yang berbeda. Kedua, kemampuan imlementasi perusahaan yang bersangkutan mempengaruhi pemilihan oleh strategi manajemen. Sebagai contoh, manajemen akan menghindari suatu serangan frontal yang luas melawan sebuah pesaing yang kuat dan bertahannya apabila perusahaan itu tidak memiliki sumberdaya yang cukup untuk menjalankan strategi tersebut (Wilhelmus, 1986).

\section{ANALISIS DAN PEMBAHASAN}

Aktifitas pemasaran produk yang dilakukan oleh PT. Asuransi Asei cabang Padang merupakan suatu cara untuk mencapai tujuan dan menggambarkan bagaimana sebuah perusahaan harus beroperasi dengan suatu tujuan tertentu. Karena pemasaran merupakan suatu kegiatan usaha yang berkaitan dengan mengalirnya barang dan jasa dari produsen sampai ke konsumen. Strategi pemasaran pada dasarnya merupakan rencana yang menyeluruh dan menyatu dalam bidang pemasaran, yang akan memberikan panduan tentang kegiatan yang dijalankan agar tercapainya suatu tujuan pemasaran atau perusahaan. Dengan kata 
lain, strategi pemasaran merupakan tujuan dan sasaran yang memberi arah kepada suatu usaha perusahaan dari waktu kewaktu.

Masing-masing dari faktor terkait dengan fungsi perusahaan tersebut dapat merupakan suatu hal yang menujukkan keunggulan dan kelemahan perusahaan, khusus dalam bidang pemasaran. Faktor lingkungan yang teleh diuraikan diatas, adalah faktor yang tidak dapat dikendalikan oleh pimpinan perusahaan. Sedangkan faktor internal dalam bidang pemasaran adalah faktor yang dapat dikendalikan oleh pimpinan perusahaan umumnya dan pimpinan pemasaran khusnya, yang terdiri dari produk, harga penyaluran/distribusi, promosi dan pelayanan.Strategi pemesaran memiliki tiga komponen yakni segmentation, targeting, positioning (Mutia, 2019)

\section{a. Segmentation}

Secara umum, tujuan utama dari perusahaan adalah untuk menghasilkan laba. Agar tujuan tercapai maka suatu perusahaan harus memasarkan produk-produk yang dihasilkan ke daerah-daerah pemasaran yang potensial baik yang sudah dimasuki maupun yang belum dimasuki. Oleh karena itu perusahaan harus menentukan siapa yang menjadi sasaran dari pemasarannya, atau harus menetapkan segmentasi pasarnya terlebih dahulu. Karena segmentasi pasar merupakan konsep yang penting dalam memasarkan produk dan jasa. Pasar terdiri dari banyak tipe pelanggan, produk, dan kebutuhan. Pemasar wajib menetukan pasar mana yang menawarkan peluang terbaik. Konsumen dapat dikelompokkan serta dilayani dari berbagai macam cara berdasarkan faktor geografis, demografis, spikografis dan prilaku.

b. Targetting

Setelah perusahaan mendefinikasikan segmen pasar, maka perusahaan dapat memasuki satu atau beberapa segmen pasar yang menjadi fokus kegiatan pemasaran. Targeting disebut juga selecting karena Merketer harus menyeleksi. Perusahaan menargetkan daya tarik segmen perusahaan yang menghasilkan nilai pelanggan terbesar dan mempertahankannya sepanjang waktu. Target pasar terdiri dari jumlah pembeli yang berbagai kebutuhan dan karateristik sama akan dilayani perusahaan.

c. Positioning

Setelah memutuskan segmen pasar mana yang dimasuki, perusahaan harus menentukan bagaimana cara untuk penawaran setiap segmen pasar tersebut. Positioning merupakan pengaturan produk untuk menduduki suatu tempat yang berbeda dan diinginka relative terhadap saingan produk dalam pikiran konsumen. Pemasar ingin mengembangkan posisi pasar yang unik bagi produk mereka, jika semua produk yang di anggap persis dengan produk lainya dipasar, konsumen tidak memiliki alasan untuk membelinya. Oleh karena itu, pemasar harus merencanakan posisi yang berbeda produk dari merek pesaing serta memberikan mereka manfaat yang besar dalam target pasar. 


\section{Produk-Produk Asuransi Umum Pada PT. Asuransi Asei}

Asuransi ini merupakan pengulangan dari risiko atas kerugian, kehilangan manfaat, dan tanggung jawab hukum kepada pihak ketiga yang timbul dari peristiwa yang tidak pasti. Adapun jenis-jenis asuransi umum diantaranya:

\section{a. Asuransi Harta Benda}

Jenis asuransi harta benda bertujuan memberikan ganti rugi kepada tertanggung, atas kerusakan/kerugian harta benda yang dipertanggungkan yang dsebabkan oleh kebakaran, sambaran petir, ledakan, kejatuhan pesawat terbang yang dipertanggungkan. Adapun jenis asuransi yang dicakup oleh harta benda diantaranya yakni:

1) Polis Standar Asuransi Kebakaran Indonesia (PSAKI), PSAKI merupakan polis yang menutup pertanggungan atas kerugian harta benda (bangunan beserta isisnya) yang disebabkan karena kebakaran atau sebab lain yang disebut dalam kontrak pertanggungan.

2) Asuransi Property All Risk (PAR) Jenis asuransi ini merupakan asuransi yang paling popular dibandingkan dengan asuransi lainnya, karena asuransi ini menjamin semua risiko kecuali kerugian yang tercantum dalam pengendalian.

3) Polis Standar Asuransi Gempa Bumi Indonesia (PSAGBI), asuransi ini menjamin kerusakan seperti bangunan, pabrik, dan rumah yang diakibatkan gempa bumi, letusan gunung, berapi dan tsunami.

4) Asuransi Terrorisme and Sabotoge (TAS) jenis asuransi yang memberikan jaminan perlindungan terhadap kerusakan/kerugian objek pertanggungan akibat tindakan Terrorisme dan Sobotase. Adapun pihak yang dapat menjadi tertanggung adalah perusahaan dan perorangan langsung/instansi.

5) Asuransi Business Interruption (BI), jenis asuransi ini yang memberikan jaminan atas kerugian/kehilangan pendapatan dari usaha tertanggantung yang diakibatkan terhadap harta benda yang dipertanggungkan, akan mengganti kehilangan/kerugian dana yang diperlukan untuk menjalankan usaha sebagai akibat dari terjadinya risiko. Pihak yang menjadi tertanggung adalah perusahaan dan perorangan langsung/instansi.

\section{b. Asuransi Rekayasa}

Asuransi rekayasa menjamin kerugian dari akibat kerusakan material (pada mesin, peralatan elektronik, dan lainnya) atau kerugian akibat tanggungjawab terhadap pihak ketiga yang terjadi selama masa pembangunan atau pada saat pemasangan. Adapun yang dicakup oleh asuransi rekayasa diantaranya:

1) Engineering proyek

a) Asuransi Kontruksi, asuransi ini menjamin semua risiko kerusakan/kerugian yang terjadi selama proses pembangunan atau kontruksi.

b) Asuransi Pemasangan, asuransi ini menjamin semua risiko kerusakan/kerugian yang terjadi selama proses pemasangan/istalasi mesin-mesin. 
c) Asuransi Contractor's, asuransi ini menjamin semua risiko kerusakan/kerugian fisik atau objek pertanggungan yang terjadi dan sifatnya tak terduga. Asuransi ini juga menjamin kerusakan pada saat alat-alat sedang bekerja/dioperasikan, dibongkar (dalam proses perawatan). Pihak yang menjadi tertanggung adalah kontraktor, perusahaan, dan perorangan langsung/intansi.

2) Non Engineering Non proyek

a) Asuransin Peralatan Elektronik, asuransi ini menjamin kerugian/kerusakan akibat fisik pada peralatan elektronik.

b) Asuransi Kerusakan Mesin, asuransi ini mejamin atas mesin instalasi pabrik yang sedang dalam dioperasikan.

c) Comprehensive Machinery Insurance (CMI) yakni memberikan jaminan perlindungan kepada tertanggung terhadap kerugian/kerusakan pada mesin atas semua risiko yang bersifat didominasi rekayasa, khusnya risiko-risiko akibat kebakaran, petir serta ledakan kimia, atas bahaya alam. Pihak yang dapat menjadi tertanggung adalah perusahaan dan perorangan langsung/ instansi.

3) Asuransi Pengangkutan Barang/Marine Cargo Insurance.

Asuransi ini memberikan perlindungan kepada tertanggung dari kerusakan/kerugian atas barang-barang yang diangkut (yang sedang dalam pengangkutan) sebagai akibat suatu musibah/kecelakaan.

4) Asuransi Rangka Kapal

Jenis asuransi ini memberikan jaminan atas kerugian/kerusakan dan kehilangan rangka kapal, seperti mesin penggeraknya, yang dijamin dalam kondisi akibat dari risiko-risiko yang dijamin dalam kondisi polis.

5) Asuransi Minyak dan Gas Bumi

Jenis asuransi ini menjamin kerusakan/kerugian pada peralatan eksplorasi dan produksi minyak baik didarat maupun dilaut.

6) Asuransi Tanggung Gugat

Asuransi ini menjamin atas tanggungjawab hukum terhadap pihak ketiga baik berupa cidera badan, dan kerusakan harta benda sehubungan dengan aktivitas pekerjaan atau bisnis yang dijalankan oleh tertanggung.

7) Asuransi kecelakaan diri

Asuransi kecelakaan diri menjamin atas risiko kematian, cacat tetap, cacat sementara, biaya perawatan atau pengobatan yang secara langsung disebabkan oleh suatu kecelakaan. Asuransi kecelakaan diri mencakup polis standar asuransi kecelakaan diri Indonesia (PSAKDI).

8) Asuransi kendaraan bermotor

Asuransi yang memberikan jaminan atas kerugian/kehilangan kendaraan bermotor roda empat dan roda dua yang dipertanggungkan oleh peserta. 


\section{SIMPULAN}

Berdasarkan pembahasan yang telah dibahas dalam bab sebelumnya maka penulis mengambil kesimpulan sebagai berikut:

1. Pemasaran merupakan hasil prestasi kerja kegiatan usaha, yang berkaitan dengan mengalirnya barang dan jasa dari produsen sampai ke konsumen.

2. Untuk meningkatkan penjualan dan menguasai pangsa pasar, maka diperlukan strategi pemasaran, karena Strategi pemesaran merupakan salah satu keberhasilan usaha perusahaan umumnya dibidang pemasaran khususnya.

3. Hasil dari uraian diatas menunjukkan bahwa PT. Asuransi Asei cabang Padang memiliki tantangan yang besar. Artinya usaha tersebut dalam kondisi yang mantap namun memiliki sejumlah tantangan yang besar. Didalam lingkup pemasaran terdapat beberapa unit kesatuan yang dapat dipasarkan diantaranya yakni, Barang, jasa, events, orang, Place atau tempat, Properties, Organisasi, informasi, Gagasan atau idea ,Pemasar atau marketer.

\section{UCAPAN TERIMA KASIH}

Penulis ucapkan puji syukur atas kehadirat Allah SWT, yang telah melimpahkan rahmat dan hidayah-Nya kepada penulis. Penulis ingin mengucapkan terima kasih sebanyak-banyaknya atas bimbingan Bapak Muhammad Hendra, SE, MM dan PT. Asuransi Asei Cabang Padang yang telah memberikan motivasi, masukan-masukan yang bermanfaat bagi penulis dan terima kasih untuk teman-teman atas semangat dan dukungannya dalam pembuatan artikel ini. Akhir kata penulis ucapkan terima kasih. Semoga apa yang penulis tuangkan dalam artikel ini memberikan manfaat terutama bagi saya sendiri selaku penulis. Aamiin ya Rabbal'alamin.

\section{DAFTAR PUSTAKA}

Assauri, S. (2019a). Manajemen Bisnis Pemasaran. PT Rajagrafindo Persada.

Assauri, S. (2019b). Manajemen Pemasaran. PT Rajagrafindo Persada.

Hidayati, R. R., \& Marlius, D. (2018). Aktivitas Promosi Dalam Meningkatkan Dana Pihak Ketiga Pada PT. Bank Perkreditan Rakyat (BPR) Batang Kapas Pesisir Selatan. https://doi.org/10.31227/osf.io/8dgqn

Khotler Philip. (1994). Manajemen Pemasaran. PT. Gelora Aksara Pratama.

Khotler Philip. (2012). Manajemen pemasaran. PT. Gelora Aksara Pratama.

Makdalena, M. (2015). Pengaruh Model Iklan Dan Harga Terhadap Keputusan Pembelian Sabun Loox Masyarakat Kecamakan IV Jurai Kap. PES-SEL. Vol. 3, No.

Marlius, D. (2016). Pengaruh Bauran Pemasaran Jasa Terhadap Minat Nasabah Dalam Menabung Pada Bank Nagari Cabang Muaralabuh. 
https://doi.org/10.31227/osf.io/vdqgx

Marlius, D., \& Nurfazila, N. (2020). Aktivitas Pemasaran Tabungan Pada Pt. Bank Pembangunan Daerah Sumatera Barat Cabang Pembantu Tarusan. https://doi.org/10.31219/osf.io/fvqc7

Mutia, S. (2019). Analisis Strategi Pemasaran Dalam Penjualan Produk Asuransi Kebakaran Pada PT. Asuransi Asei cabang Medan. universitas islam negeri sumatera utara medan.

Nurdin. (2016). Analisis Strategi Pemasaran Dan Penjualan E-Commerce Pada tokopedia.com. vol 2 No 1.

Ratnasari. (2016). Pengaruh Kualitas Produk Dan Citra Merek Terhadap Keputusan Pembelian Produk Fungisida Pt. Bayer Cropscience Pada Para Petani Di Kecamatan Rawamerta. vol 15 No.

Widayati, R. (2019). Aktivitas Pemasaran Produk Simpanan PT. Bank Tabungan Negara (Persero)Tbk Kantor Cabang Padang. https://doi.org/10.17605/OSF.IO/3Z5YC

Widayati, R. (2019). Aktivitas Pemasaran Produk Tabungan Pada PT. Bpr Rangkiang Denai Payakumbuh Barat. https://doi.org/10.17605/OSF.IO/S3UZM 